\title{
KONDISI TEGAKAN MERANTI TEMBAGA (Shorea leprosula) \\ DI KAWASAN BEKAS KEBAKARAN SAMBOJA, KALIMANTAN TIMUR
}

(Stand condition of Meranti tembaga (Shorea leprosula) in the post fire area in Samboja, East Kalimantan)

Oleh/By :

\section{Ayi Suyana dan/and Abdurrachman}

\section{Balai Besar Penelitian Dipterokarpa, Samarinda}

\begin{abstract}
Rehabilitation activities in ex forest fire areas, need to be done with various plant genus, especially local indigenous species. This research was done on heavily burnt forest areas in Samboja, East Kalimantan. The purpose of this research was to examine condition of Meranti tembaga (Shorea leprosula) stands on ex forest-fire areas at the age of 13 years. The results show that the structure of the stand was considered as Bell shape or normal curve. Increment of diameter was $1.26 \mathrm{~cm}$ per year, and $1.27 \mathrm{~m}$ peryear for the height. Tree can be said slim enough with comparation rate height and diameter was 105, 48 .
\end{abstract}

Keyword: Structure, Stand, Meranti Tembaga (Shorea leprosula), Increment

\begin{abstract}
ABSTRAK
Kegiatan merehabilitasi hutan bekas terbakar baik ringan, sedang maupun berat pada suatu tempat perlu dilakukan melalui usaha penanaman dengan berbagai jenis tanaman terutama jenis asli setempat. Penelitian ini dilaksanakan pada areal hutan bekas terbakar berat. Tujuan dari penelitian ini adalah untuk mengetahui kondisi tegakan Meranti Tembaga (Shorea leprosula) yang ditanam pada areal bekas terbakar berat pada umur 13 tahun. Hasil pengamatan menunjukkan bahwa Struktur tegakan memiliki bentuk Genta atau kurva Normal. Nilai rataan riap sebesar $1.26 \mathrm{~cm}$ pertahun untuk diameter dan $1.27 \mathrm{~m}$ pertahun untuk tinggi. Pohon dapat dikatakan cukup ramping dengan rataan nisbah tinggi dengan diameter sebesar 105.48.
\end{abstract}

Kata Kunci : Struktur tegakan, meranti tembaga (Shorea leprosula), riap 


\section{PENDAHULUAN}

Kebakaran areal atau hutan dapat terjadi kapan saja dan di mana saja, baik yang disebabkan oleh faktor kesengajaan maupun tidak dan juga bisa disebabkan oleh manusia maupun oleh alam karena disambar petir atau kemarau yang berkepanjangan yang dapat menimbulkan api akibat gesekan bahan kering yang ada didalam hutan.

Kegiatan rehabilitasi hutan bekas terbakar baik ringan, sedang maupun berat pada suatu tempat perlu dilakukan dengan melakukan penanaman dengan berbagai jenis tanaman terutama jenis asli setempat.

Kebakaran hutan di Kalimantan Timur yang dimulai tahun 1982/1983 terjadi pada setiap periode 5 tahun dan terakhir pada tahun 1997/1998, membawa dampak bagi kerusakan areal. Hal ini juga terjadi di areal demplot penelitian Samboja. Akibat dari kebakaran tersebut banyak hutan yang telah ditanam, bekas tebangan, dan ladang yang rusak, termasuk areal demplot penelitian Samboja.

Dengan kondisi tersebut maka perlu dilakukan usaha-usaha penanaman, baik pada hutan alam dalam bentuk pengayaan dan rehabilitasi maupun membangun hutan tanaman. Untuk itu diperlukan berbagai informasi dari berbagai jenis tumbuhan terutama dari berbagai jenis tanaman terutama jenis tumbuhan.

Project IITO PD 84/90 (F) phase 2 tahun mencoba melaksanakan kegiatan rehabilitasi pada areal yang terbakar berat dengan menanam tanaman dari jenis Meranti tembaga (Shorea leprosula) dengan jarak tanam $6 \mathrm{~m} \times 4 \mathrm{~m}$. Sistem pemeliharaan yang dilakukan adalah sistem jalur.

Meranti tembaga merupakan salah satu jenis komersial dari marga Shorea termasuk ke dalam famili Dipterocarpaceae. Di Indonesia Meranti ini tersebar di Sumatera dan Kalimatan. Jenis ini tumbuh di dalam hutan primer pada berbagai dataran rendah atau di atas perbukitan sampai dengan ketinggian $400 \mathrm{~m}$ dpl. Pohon ini memiliki ukuran yang sangat besar, tingginya dapat mencapai $60 \mathrm{~m}$ sedangkan diameternya $100 \mathrm{~cm}$ atau lebih. Kulit batang berwarna abu-abu kecoklatan, beralur dan mengelupas agak besar. Dengan ukuran yang besar maka kayu ini sangat baik untuk bahan pertukangan. Biasanya digunakan untuk bangunan, kayu lapis, mebel, lantai, papan dinding dll. Berat jenis dari kayu ini adalah 0.52 (kisaran antara $0.30-0.86$ ), dengan kelas keawetan III-V dan kelas kekuatan III-IV (Heyne, 1987, Anonim, 1994 dan Martawijaya, et al, 2005).

Berdasarkan hal di atas maka pada tulisan ini akan disampaikan informasi kondisi tegakan tanaman dari jenis Meranti Tembaga (Shorea leprosula) di kawasan bekas kebakaran. 


\section{RISALAH UMUM LOKASI PENELITIAN}

Secara geografis daerah penelitian ini berada sekitar 00'59'36,4" Lintang Se-latan (LS) dan 116 55'29,2" Bujur Timur (BT) dengan ketinggian antara 50-90 m dpl. Kawasan hutan Bukit Soeharto memiliki jenis tanah Podsolik Merah Kuning dan terletak di daerah lipatan dengan bentuk wilayah bergelombang sampai berbukit.

Perkembangan profil tanah tersebut dari batuan liat dan batu pasir. Fraksi pasir terdiri dari kwarsa keruh dengan fragmen batuan kwarsit. Konkresi besi dan mineral lapuk, sedangkan kandungan mineralnya sangat rendah.

Tanah bagian atas mempunyai struktur rendah dengan konsistensi gembur sedangkan bagian bawah mempunyai struktur rendah sampai gempal dengan konsistensi gembur sampai teguh. Tekstur tanah lempung berdebu dengan laju perkolasi agak lambat.

Curah hujan rata-rata tahunan yang diambil dari stasiun klimatologi yang ada pada daerah ini adalah $2.355 \mathrm{~mm} /$ tahun. Temperatur udara maksimum pada siang hari mencapai $32,77^{\circ} \mathrm{C}$ dan minimum $29,10^{\circ} \mathrm{C}$. Suhu udara maksimum pada malam hari adalah $24,26^{\circ} \mathrm{C}$ dan minimum $23,26^{\circ} \mathrm{C}$.

Lokasi ini telah mengalami kebakaran yang berulang-ulang sehingga telah mengalami suksesi yaitu suatu penggantian oleh komunitas tumbuh-tumbuhan yang lain. Hal ini dapat terjadi pada tahap integrasi lambat ketika tempat tumbuh mula-mula sangat keras sehingga sedikit tumbuhan dapat hidup di atasnya atau suksesi tersebut dapat terjadi sangat cepat ketika suatu komunitas dirusak oleh suatu faktor seperti api, banjir atau epidemi serangga dan diganti oleh yang lain(Daniel et al., 1987).

\section{METODE PENELITIAN}

\section{A. Pengambilan Data}

Data yang diambil untuk penelitian ini adalah tanaman yang telah ditanam pada tahun 1994 dengan jarak tanam $6 \mathrm{~m}$ x $4 \mathrm{~m}$. Dari tanaman yang ada tersebut dilakukan pengukuran secara sensus untuk pengukuran diameter dan tinggi.

\section{B. Cara Pengukuran}

Pengukuran tinggi total pada semua pohon dengan menggunakan clinometer. Alat ukur tinggi clinometer digunakan menurut kaidah ilmu ukur segitiga (trigonometri). Dengan perbandingan besaran sudut-sudut yang dibentuk oleh garis-garis pandang pada tinggi pohon berdiri dan dengan bantuan galah yang di-ketahui panjangnnya, maka nilai tinggi diperoleh dengan rumus (Ruchaemi, 2003; Sutarahardja, 1979): 


$$
H=\frac{H_{t o p}-H_{b}}{H_{p}-H_{b}} \times 4 m
$$

Dimana :

$\mathrm{H}_{\text {top }} \quad$ : skala persen puncak pohon

$\mathrm{H}_{\mathrm{p}} \quad$ : skala persen ujung galah

$\mathrm{H}_{\mathrm{b}} \quad$ : skala persen ujung pohon

$4 \mathrm{~m}$ : tinggi galah

Pengukuran diameter setinggi dada dilakukan dengan menggunakan alat ukur panjang sehingga yang diperoleh adalah nilai keliling yang kemudian dikonversi menjadi diameter dengan dibagi dengan nilai pi yaitu 3,14.

\section{HASIL DAN PEMBAHASAN}

\section{A. Sebaran Diameter}

Data hasil pengukuran di lapangan yang disajikan pada Tabel 1 dikelompokkan dalam kelas-kelas diameter dengan interval $5 \mathrm{~cm}$.

Tabel(Table) 1. Sebaran diameter tanaman Meranti tembaga (S. leprosula) di lokasi penelitian (Distribution of diameter of Meranti Tembaga (S. leprosula) plantation in research site)

\begin{tabular}{|c|c|c|}
\hline $\begin{array}{c}\text { Kelas diameter } \\
(\text { Diameter class })(\mathrm{cm})\end{array}$ & $\begin{array}{c}\text { Nilai tengah } \\
(\text { median })\end{array}$ & $\begin{array}{c}\text { Jumlah pohon } \\
(\text { Number } \text { of trees })\end{array}$ \\
\hline $0,00-4.99$ & 2.50 & 1 \\
\hline $5,00-9.99$ & 7.50 & 23 \\
\hline $10,00-14.99$ & 12.50 & 67 \\
\hline $15.00-19$ & 17.50 & 68 \\
\hline $20,00-24.99$ & 22.50 & 40 \\
\hline $25,00-29.99$ & 27.50 & 13 \\
\hline $30,00-34.99$ & 32.50 & 2 \\
\hline
\end{tabular}

Dari Tabel 1 tersebut terlihat bahwa jumlah pohon terbanyak berada pada kelas diameter pertengahan atau di antara diameter yang terbesar dan terkecil. Sedikit sekali pohon yang telah mencapai diameter diatas $25 \mathrm{~cm}$ walaupun umurnya telah mencapai 13 tahun. Pohon-pohon terbanyak pada kelas diameter $10-15 \mathrm{~cm}$. Selanjutnya dari sebaran yang ada terlihat bahwa ada pohon yang hidupnya sangat tertekan dengan diameter $<5 \mathrm{~cm}$ akan tetapi masih bertahan hidup. Sebaliknya terdapat pula pohon yang perkembangannya melebihi dari yang lain. Hal ini memperlihatkan adanya persaingan dalam pertumbuhan pohon dalam suatu tegakan.

Bentuk sebaran dari tanaman tersebut dapat dilihat pada Gambar 1 berikut ini : 


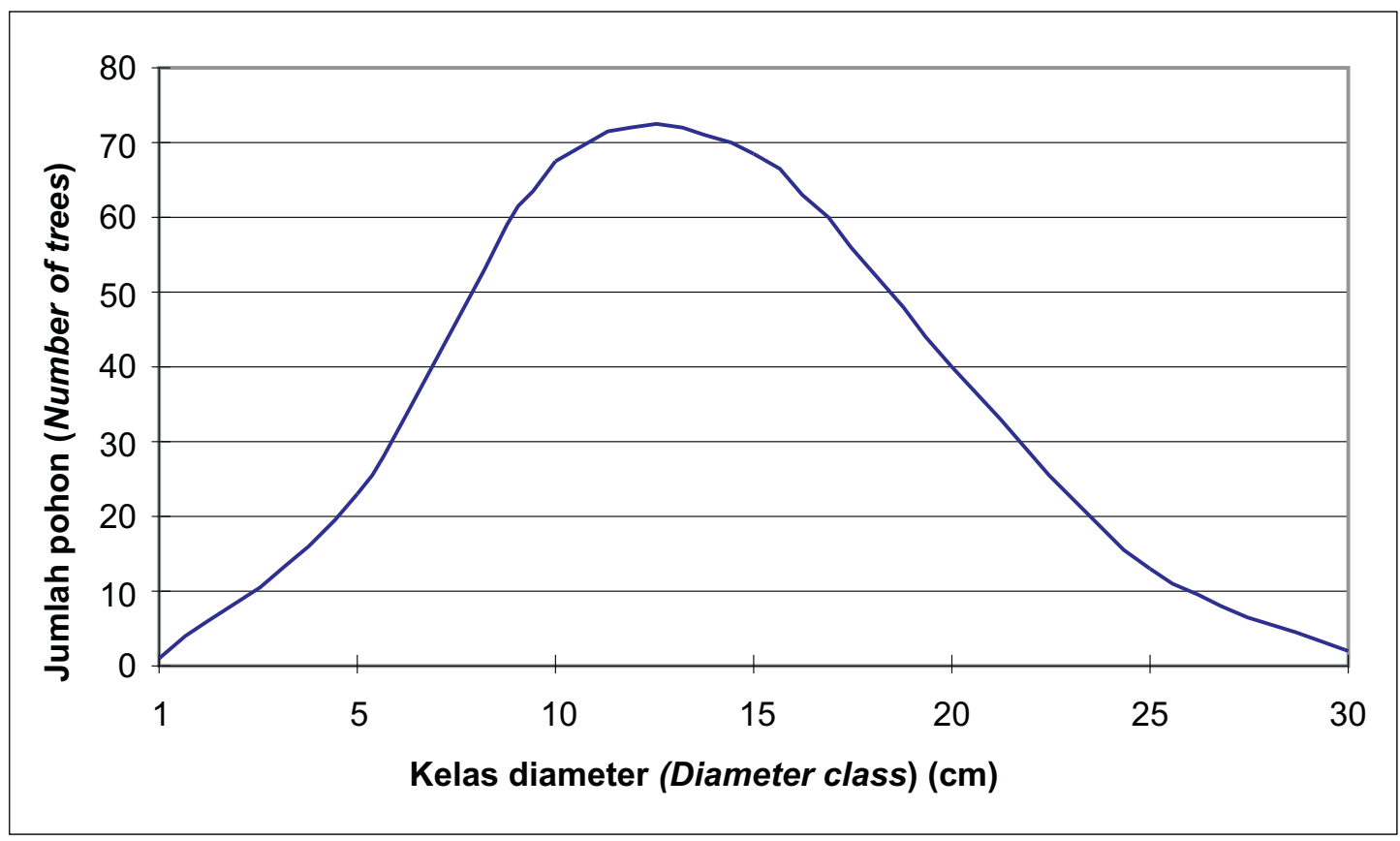

Gambar(Figure) 1. Kurva sebaran diameter tanaman Meranti tembaga (S. leprosula) di lokasi penelitian (Curve of diameter distribution of Meranti tembaga (S. leprosula) plantation in research site)

Pada Gambar 1 tersebut terlihat bahwa kurva sebaran diameter hampir menyerupai bentuk lonceng/genta yang menunjukkan sebaran normal. Kondisi kurva yang menyerupai lonceng/genta ini merupakan ciri dari hutan tanaman, seperti yang terlihat pada penelitian di hutan tanaman meranti di KHDTK Sebulu (Suyana dan Abdurachman, 2006), tanaman Acacia mangium di PT. ITCI Kenangan (Rizal, 1987). Perlakuan di hutan tanaman adalah suatu usaha dalam rangka memperoleh hasil atau volume yang besar sehingga dalam proses yang lebih jauh pada hutan tanaman diperlukan suatu upaya untuk menggeser bentuk kurva ini pada area di sekitar titik puncak ke arah sebelah kanan pada sumbu $\mathrm{X}$ sehingga hasil produksi yang diperoleh menjadi besar. Demikian pula jika tanaman ini akan ditujukan untuk maksud tersebut maka pada tahap selanjutnya diperlukan perlakuan-perlakuan dalam usaha tersebut. Secara teoritis, teknik silvikultur diperlukan untuk menggeser kurva tersebut kearah kanan.

\section{B. Statistik Tanaman}

Statistik diameter dan tinggi tanaman Meranti tembaga ( $S$. leprosula) yang diukur pada umur 13 tahun disajikan pada Tabel 2. 
Tabel (Table) 2. Statistik diameter dan tinggi tanaman Meranti tembaga (S. leprosula) di lokasi penelitian (Statistics of diameter and height of Meranti tembaga (S. leprosula) plantation in research field)

\begin{tabular}{|l|r|r|r|r|}
\hline \multicolumn{1}{|c|}{ Peubah ( variable) } & $\begin{array}{c}\text { Rataan } \\
(\text { Mean })\end{array}$ & $\begin{array}{c}\text { Maksimum } \\
(\text { Maximum })\end{array}$ & $\begin{array}{c}\text { Minimum } \\
(\text { Minimum })\end{array}$ & $\begin{array}{c}\text { Variasi } \\
\text { (variance })\end{array}$ \\
\hline Diameter $($ dimater $)(\mathrm{cm})$ & 16.4257 & 32.7859 & 4.5837 & 29.7394 \\
\hline Tinggi $($ height $)(\mathrm{m})$ & 16.4453 & 27.5 & 7.5 & 16.3741 \\
\hline
\end{tabular}

Tabel 2 di atas menyajikan lebar rentang ukuran dari diameter dan tinggi. Nilai rataan pengukuran yang memiliki nilai yang cukup jauh dari nilai maksimum dan minimum memberikan indikasi variasi nilai yang besar. Hal tersebut ditunjukkan pada nilai-nilai statistik dari tabel tersebut. Hal ini juga menunjukkan adanya pohon yang tertekan.

Selanjutnya pada Gambar 2 berikut diperlihatkan model hubungan diameter dan tinggi dari tanaman Meranti tembaga (S. leprosula)

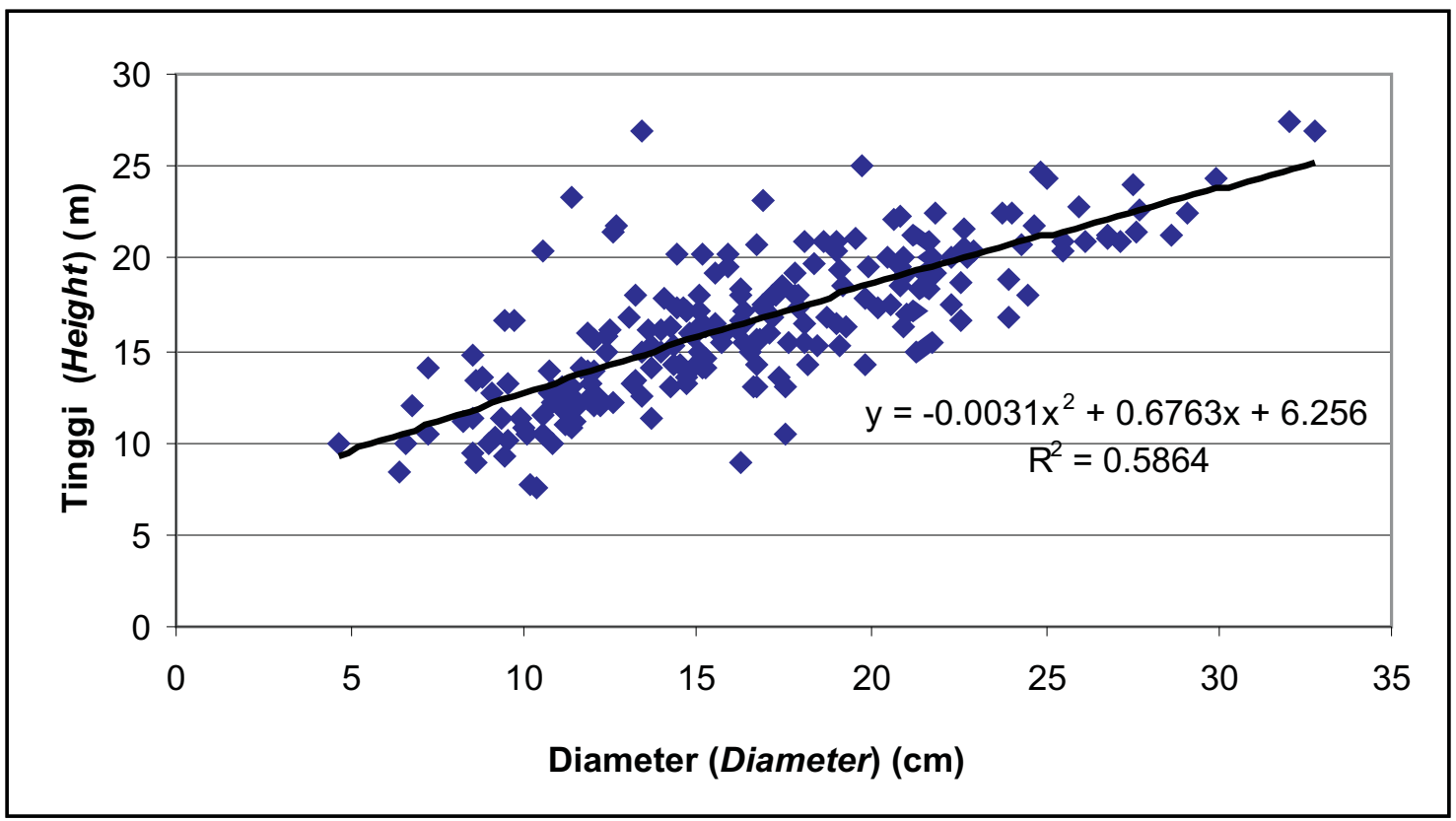

Gambar(Figure)2. Model regresi hubungan diameter dan tinggi pada pertumbuhan tanaman Meranti tembaga ( $S$. leprosula) di lokasi penelitian (Regression model of relationship between diameter and heght at growth Meranti tembaga (S. leprosula) plantation in research field)

Dari gambar tersebut terlihat bahwa pertumbuhan diameter memiliki hubungan yang cukup erat dengan pertumbuhan tinggi dimana hal ini ditunjukkan dengan nilai koefisien Determinasi $\left(\mathrm{R}^{2}\right)$ sebesar 0.5864 atau koefisien korelasi (r) sebesar 0.7657. Selanjutnya keeratan hubungan antara diameter dan tinggi ini dapat diuji dengan nilai r-tabel pada taraf signifikansi 0.01 yang memiliki nilai 0,175 dengan derajat bebas $(n-2)=212$. Dari hasil perhitungan di atas maka nilai r-hitung $(0.766)>$ r-tabel $(0,175)$ sehingga diantara keduanya peubah tersebut terdapat hubungan yang 
signifikan.

Untuk melihat tingkat signifikansi keeratan dari pertumbuhan diameter dan tinggi dilakukan analisis varians. Hasil analisis ditunjukkan dalam tabel Analisis Varians (Anova) berikut.

Tabel(Table)3. Analisis Varian (ANOVA) hubungan pertumbuhan diameter dan tinggi untuk tanaman Meranti tembaga (S. leprosula) di lokasi penelitian (Analysis of variance of relationship between growth of diameter and height of Meranti tembaga $(S$. leprosula)plantation in research site)

\begin{tabular}{|l|r|r|r|c|c|}
\hline $\begin{array}{c}\text { Variabel } \\
\text { (Variable) }\end{array}$ & $\begin{array}{c}\text { Derajat bebas } \\
\text { (degreeof freedom) }\end{array}$ & $\begin{array}{c}\text { Jumlah Kuadrat } \\
\text { (Sum of Square) }\end{array}$ & $\begin{array}{c}\text { Rataan Kuadrat } \\
\text { (Mean of square) }\end{array}$ & Fhit & $\mathrm{F}_{\text {tab99\% }}$ \\
\hline Regresi (Regression) & 2 & 2045.323 & 1022.662 & 149.6023 & 4.61 \\
\hline Sisa (Residual) & 211 & 1442.368 & 6.835868 & & \\
\hline Jumlah (Total) & 213 & 3487.691 & & & \\
\hline
\end{tabular}

Hasil analisis varians menunjukkan bahwa besarnya nilai $\mathrm{F}$ hitung $>\mathrm{F}$ tabel $99 \%$ yang memberikan arti bahwa keduanya memiliki hubungan yang sangat signifikan dimana dengan bertambahnya diameter akan berpengaruh terhadap pertumbuhan tinggi.

\section{Riap Tanaman}

Hasil perhitungan riap tanaman per tahun (Mean Annual Increment/MAI) untuk diameter dan tinggi dapat dilihat pada Tabel 3 berikut ini :

Tabel (Table) 3. Riap diameter dan tinggi tanaman di lokasi penelitian (Increment of diameter and height in research site)

\begin{tabular}{|l|r|r|r|r|r|}
\hline \multicolumn{1}{|c|}{ Riap (Increment) } & $\begin{array}{l}\text { Rataan } \\
\text { (Mean) }\end{array}$ & $\begin{array}{l}\text { Maksimum } \\
\text { (Maximum) }\end{array}$ & $\begin{array}{c}\text { Minimum } \\
\text { (Minimum) })\end{array}$ & $\begin{array}{c}\text { Kesalahan baku } \\
\text { (Standard } \\
\text { deviation })\end{array}$ & $\begin{array}{c}\text { Variasi } \\
\text { (variance })\end{array}$ \\
\hline $\begin{array}{l}\text { Diameter } \\
(\text { diameter })(\mathrm{cm})\end{array}$ & 1.2635 & 2.5220 & 0.3526 & 0.4195 & 0.1760 \\
\hline Tinggi $($ height $)(\mathrm{m})$ & 1.2650 & 2.1154 & 0.5769 & 0.3113 & 0.0969 \\
\hline
\end{tabular}

Dari Tabel 3 di atas terlihat bahwa rataan riap diameter tanaman per tahun mencapai 1,26 $\mathrm{cm}$ per tahun dan riap rataan tinggi tanaman mencapai 1,27 $\mathrm{m}$ per tahun. Nilai-nilai ini sebenarnya didapat dari perbedaan nilai riap dengan rentang yang cukup besar sehingga nilai rataan ini tidak dapat menggambarkan nilai yang baik untuk dapat dikatakan mewakili dari nilai secara keseluruhan.

Beberapa informasi pertumbuhan Shorea leprosula antara lain yang diperoleh dari Suyana dan Abdurachman (2006) didapatkan hasil dari tegakan berumur 13 tahun dengan nilai rataan 
diameter sebesar $0.8 \mathrm{~cm}$ per tahun (jarak tanam $1 \mathrm{~m} \times 1 \mathrm{~m}$ ), $1.0 \mathrm{~cm}$ per tahun (jarak tanam $2 \mathrm{~m} \times 2 \mathrm{~m}$ ), $0.9 \mathrm{~cm}$ per tahun (jarak tanam $3 \mathrm{~m} \times 3 \mathrm{~m}$ ). Appanah dan Weinland (1993) didapatkan hasil dari tegakan berumur 40 tahun dengan nilai rataan diameter sebesar $1.84 \mathrm{~cm}$ per tahun. Sedangkan pada tanaman muda yang berumur 4,5 tahun Sukotjo (2007) didapatkan hasil rataan diameter sebesar $1,81 \mathrm{~cm}$ per tahun.

\section{Kerampingan Pohon}

Kerampingan pohon ditunjukkan berdasarkan perbandingan tinggi dan diameter (H/D). Nilai yang didapat menunjukkan bagaimana pohon tersebut membentuk dirinya untuk tetap tahan dan berdiri tegak.

Suyana (2003) menyatakan bahwa nisbah atau perbandingan tinggi dan diameter adalah angka yang menunjukkan tinggi total dibagi dengan diameter yang masing-masing mempunyai satuan yang sama, sehingga angka yang diperoleh merupakan angka indeks tanpa satuan. Angka ini penting diketahui untuk menilai bentuk arsitektur batang pohon.

Dari hasil perhitungan diperoleh nilai rataan H/D sebesar 105,48. Nilai tersebut menunjukkan bahwa pohon ini cukup ramping karenanya diperlukan perlakuan khusus pada tegakan ini untuk memacu pertumbuhan diameter untuk menghindari pohon terlalu tinggi tanpa ditopang oleh diameter yang besar. Sebagaimana diketahui jika pohon memiliki tinggi yang tidak ditopang oleh diameter yang besar akan memberikan indikasi pohon ini riskan terhadap angin. Nilai kerampingan ini adalah berbanding lurus untuk dapat memberikan informasi kekuatan tanaman. Selanjutnya Sutisna (2000) dalam Suyana (2003) berpendapat bahwa bagi pohon-pohon di hutan alam yang berperawakan bagus mempunyai angka H/D $\leq 100$. Lebih dari 100 berarti pohon "letoy" atau mudah roboh diterpa angin dan apabila kurang berarti pohon kekar.

\section{KESIMPULAN DAN SARAN}

\section{A. Kesimpulan}

Dari hasil pembahasan di atas maka dapat ditarik beberapa kesimpulan sebagai berikut :

1. Struktur tegakan atau pola sebaran diameter memiliki bentuk Genta atau kurva Normal sebagaimana sebaran pada hutan tanaman.

2. Terdapat rentang perbedaan yang besar dari besar nilai diameter dan tinggi, demikian juga dengan besarnya riap diameter dan tinggi tersebut. Walaupun demikian nilai rataan riap sebesar $1.26 \mathrm{~cm}$ per tahun untuk diameter dan $1.27 \mathrm{~m}$ per tahun untuk tinggi.

3. Pohon dapat dikatakan cukup ramping dengan rataan nisbah tinggi dengan diameter sebesar 105.48 yang berarti memiliki lebih dari nilai 100 . 


\section{B. Saran}

Hasil pengamatan ini merupakan informasi dari pertumbuhan Meranti tembaga (S. leprosula) sampai pada umur 13 tahun sehingga masih perlu ditindaklanjuti dengan tetap mengamatinya secara periodik. Selain hal tersebut perlu diupayakan perlakuan silvikultur untuk dapat memacu pertumbuhan diameter. 


\section{DAFTAR PUSTAKA}

Anonim 1992. Manual Kehutanan. Departemen Kehutanan. Jakarta.

Anonim 1994. Timber Trees: Major Commercial Timber. Plant Resources of South - east Asia PROSEA) No. 5 (1). Bogor.

Appanah S and G. Weinland 1993. Planting Quality Timber Trees in Peninsular Malaysia : A Review. Mal. For Res. No 38. For Res. Inst. Malaysia. Kuala Lumpur.

Daniel T.W, J.A. Helmes and F.S Baker, 1987. Prinsip-prinsip Silvikultur (Terjemahan oleh Djoko Marsono) Gadjah Mada University Press. Yogyakarta.

Davis, K.P, 1966. Forest Management. McGraw-Hill Book, Co. New York.

Evans, J. 1982. Plantatioan Forestry In the Tropiics. Clarendon Press- Oxford, New York.

Heyne, K. 1987. Tumbuhan Berguna Indonesia III (Terjemahan). Badan Penelitian dan Pengembangan Kehutanan, Departemen Kehutanan. Jakarta

Loetch, F. Zohrer, F. and Haller, K.E., 1973. Forest Inventory Vol II. Forest Inventory Section. Federal Research Organization Far Forest and Forest Products, Reinbeck. BLV. Verlagsgeselll Schaft Munchen Bern Wien.

Martawijaya. A,. I. Kartasujana, K. Kadir dan S.A. Prawira. Atlas Kayu Indonesia. Jilid I. Badan Penelitian dan Pengembangan Kehutanan, Departemen Kehutanan. Bogor

Rizal.A. 1987. Studi tentang pengaruh penjarangan terhadap pertumbuhan tegakan Aacia mangium Willd. Pada periode 1983-1987. Skripsi Fakultas Kehutanan Unmul (tidak diterbitkan). Samarinda

Ruchaemi, A. 2003. Ilmu Ukur Kayu. Laboratorium Biometrika Hutan. Fakultas Kehutanan Universitas Mulawarman. Samarinda.

Schmidt, F. H. \& J. H. A. Ferguson. 1951. Rainfall Type Based on Wet and Dry Period Ratios for Indonesia with Western New Guinea. Verhand 42. Direktorat Meteorologi dan Geofisika. Jakarta.

Snedecor, G. and W.G. Cochran. 1956. Statistical Methods Sixth Ed. The Iowa State University Press. Ames Iowa. USA

Steel, R.G.D. dan J.H. Torrie. 1993. Prinsip dan Prosedur statistika, Suatu Pendekatan Biometrika. PT. Gramedia Pustaka utama. Jakarta.

Sokotjo 2007. Pengalaman Dari Uji Jenis Dipterokarpa Umur 4,5 Tahun di PT. Sari Bumi Kusuma Kalteng. Prosiding Seminar Pengembangan Hutan Tanaman Dipterokarpa dan Ekspose TPTII/Silin. Balai Besar Penelitian Dipterokarpa. Samarinda

Sutarahardja, S. 1979. Ilmu Ukur Hutan. Fakultas Kehutanan. Institut Pertanian Bogor. Bogor

Sutisna, M 1998. Silvikultur Hutan Alam di Indonesia. Fakultas Kehutanan Universitas Mulawarman. Samarinda. 
Suyana. A, 2003. Dampak penjarangan terhadap struktur tegakan dan pertumbuhan tegakan di hutan produksi alami PT Inhutani I Labanan, kabupaten berau. Tesis Pasca sarjana, Universitas Mulawarman. Samarinda. (tidak diterbitkan)

Suyana, A dan Abdurachman, 2006. Kondisi Tegakan Shorea leprosula Miq. Umur 13 tahun pada berbagai Jarak Tanam di KHDTK Sebulu, Kabupaten Kutai Kartanegara, Kalimantan Timur. Prosiding Seminar Bersama Hasil-hasil Penelitian. Balai Litbang Kehutanan Kalimantan, Balitbang Hutan Tanaman, Loka Litbang Satwa Primata. Samarinda. 


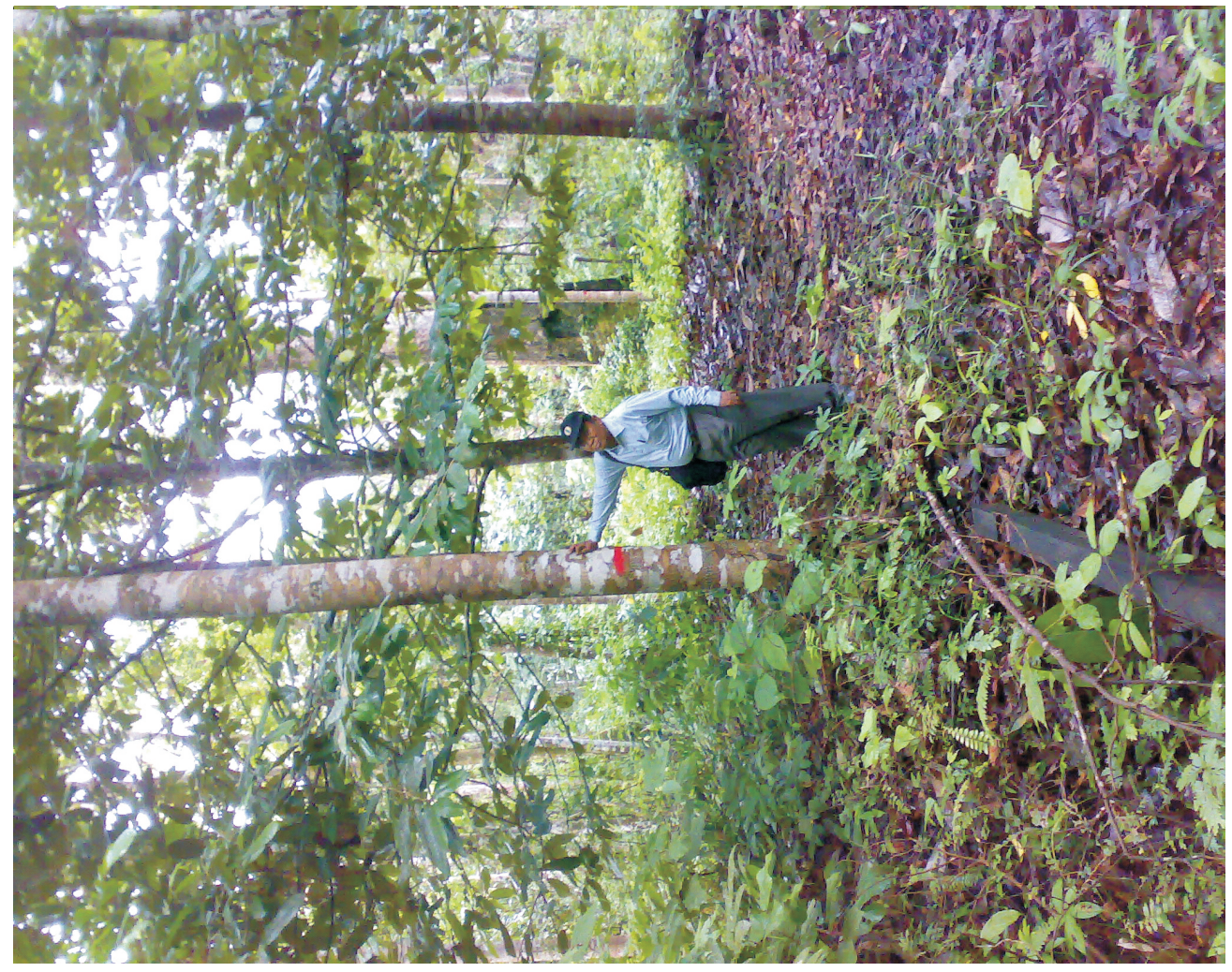

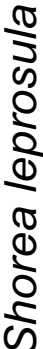

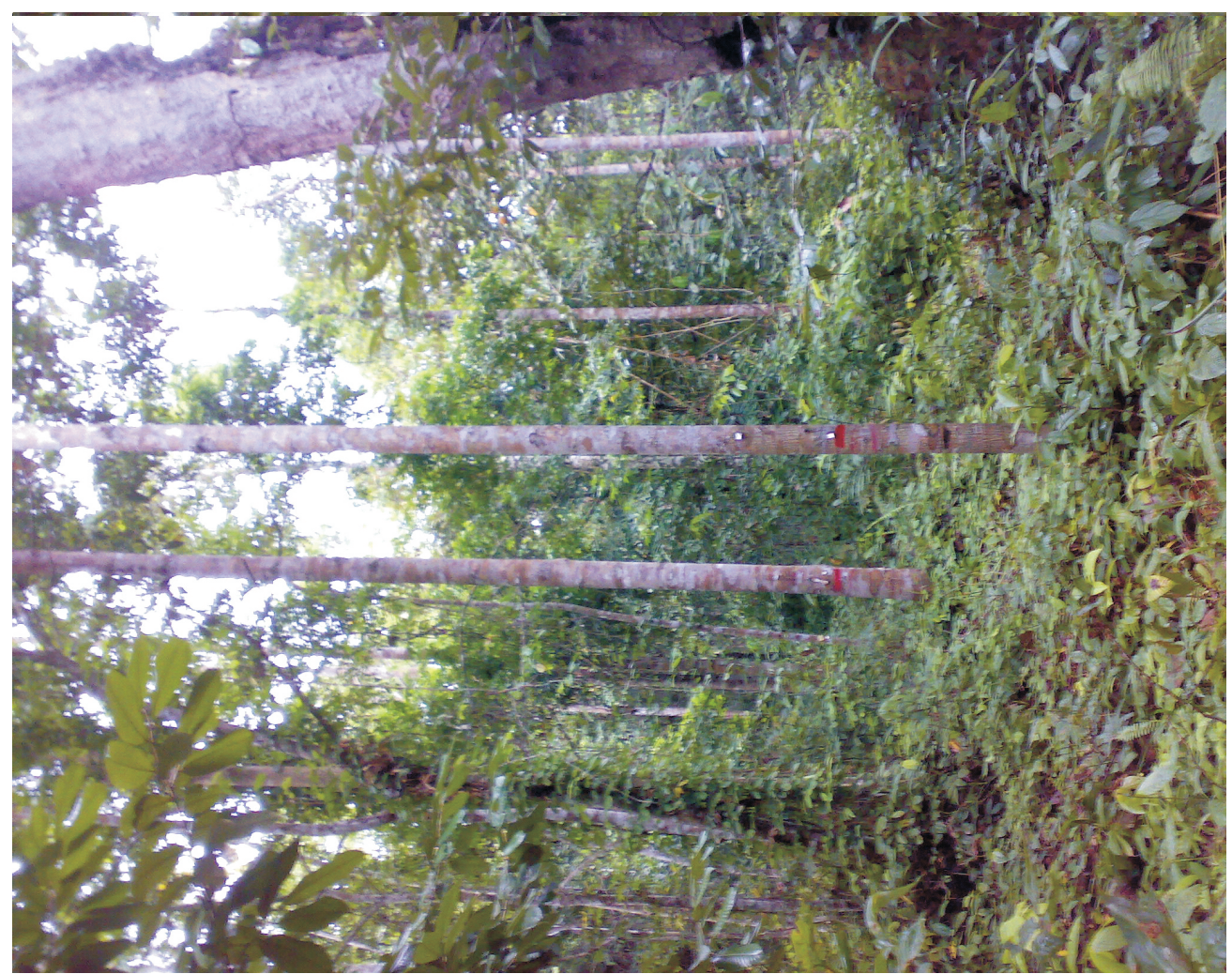

